\title{
ARTIKEL REVIEW : EFEKTIVITAS TEPUNG BIJI KELOR Moringa oleifera DALAM MENINGKATKAN KUALITAS AIR UNTUK MENUNJANG PERTUMBUHAN DAN SINTASAN IKAN MAS Cyprinus carpio L
}

Oleh

\author{
Andi Faizal Fasrih ${ }^{(1)}$, Muhajirin ${ }^{(2)}, N_{\text {Nur Hajar }}^{(3)}$, Asni Anwar $^{(4) *}$ \\ Email:andifaisal382@gmail.com, muhajirin03799@gmail.com, \\ nurhajar132@gmail.com,asni@unismuh.ac.id* \\ 1,2,3 Mahasiswa Program Studi Budidaya Perairan,Universitas Muhammadiyah Makassar \\ (4)* Dosen Program Studi Budidaya Perairan,Universitas Muhammadiyah Makassar
}

\begin{abstract}
Moringa seeds contain a bioactive compound 4-alfa-4-rhamnosyloxy benzilisothiocyanate which is able to absorb and neutralize sludge particles and metals contained in waste so it is potential to be used as a natural coagulant to clean water so it is suitable for drinking. In addition, moringa seeds contain $\pm 38 \%$ oil and in the oil contain vitamin $E$ and $\beta$ carotene each of $0.01 \%$. Old seeds contain carbohydrates, methionine, cysteine, benzyl glucosinolate, moringin, mono-palmitate and di-oleate so that they can increase fish survival and growth, so many studies have been carried out on the effectiveness of Moringa seed powder to increase production in fish farming. This review article is obtained from several journal libraries, journal searches from trusted sites. There are 4 journals as the main library, namely journals that display the results of the formulation of using moringa seed flour as a coagulant, testing water quality, evaluating survival and growth of tested fish, and the effectiveness of inhibition against the growth of Staphylococcus aureus and Escherichia coli bacteria. The results of the review show that Moringa oliefera seed flour can function as a natural coagulant for improving water quality in fish farming.
\end{abstract}

Key Word: Moringa seeds, coagulants, water quality, goldfish.

\begin{abstract}
ABSTRAK
Biji kelor mengandung senyawa bioaktif 4-alfa-4-rhamnosyloxy benzilisothiocyanate yang mampu mengabsorpsi dan menetralisir partikel-partikel lumpur serta logam yang terkandung dalam limbah sehingga sangat potensial digunakan sebagai koagulan alami untuk membersihkan air sehingga layak minum.

Selain itu biji kelor mengandung minyak dengan kadar $\pm 38 \%$ dan di dalam minyak tersebut mengandung vitamin $\mathrm{E}$ dan $\beta$ karoten masing-masing sebesar 0,01\%. Biji yang sudah tua mengandung karbohidrat, metionin, sistein, benzyl glukosinolat, moringin, monopalmitat dan dioleat yang dapat meningkatkan sintasan dan pertumbuhan ikan, sehingga banyak dilakukan penelitian terhadap efektivitas serbuk biji kelor untuk peningkatan produksi pada budidaya ikan. Metode review artikel ini diperoleh dari beberapa pustaka jurnal, penelusuran jurnal dari situs terpercaya. Terdapat 4 jurnal sebagai pustaka utama, yaitu jurnal yang menampilkan hasil dari formulasi penggunaan tepung biji kelor sebagai koagulan, pengujian kualitas air, evaluasi sintasan dan pertumbuhan ikan uji, serta efektifitas daya hambat terhadap pertumbuhan bakteri Staphylococcus aureus dan Escherichia coli. Hasil review menunjukkan bahwa tepung biji kelor Moringa oliefera efektip sebagai koagulan alami dalam meningkatkan kualitas
\end{abstract}


air kolam budidaya ikan, serta dapat meningkatkan sintasan dan pertumbuhan pada budidaya ikan mas.

Kata Kunci : biji kelor, ikan mas, koagulan, kualitas air.

\section{A. PENDAHULUAN}

Tanaman kelor sudah dikenal luas di Indonesia dan banyak ditanam sebagai pagar hidup, ditanam di sepanjang ladang atau tepi sawah, berfungsi sebagai tanaman penghijauan. Selain itu tanaman kelor juga dikenal sebagai tanaman berkhasiat obat dengan memanfaatkan seluruh bagian dari tanaman kelor mulai dari daun, kulit batang, biji, hingga akarnya (Simbolan et. Al, 2007).

Daun kelor (Moringa oleifera) dapat digunakan hingga 5\% dalam pakan sebagai pengganti tepung ikan dan bungkil kedelai (Astuti et. Al, 2005). Selanjutnya Simbolan et.al (2007) melaporkan bahwa tanaman kelor merupakan sumber provitamin A, vitamin B, vitamin (5,63-6,53 mg g-1), vitamin C (5,81-6,60 mg g-1), karotenoid (85,20$92,38 \mathrm{mg} \mathrm{g}-1)$, fenolik $(36,02-45,81 \mathrm{mg}$ g-1), flavonoid (15-27 mg g-1), dan mineral terutama zat besi. Daun kelor juga mengandung makro elemen yaitu potassium, kalsium, magnesium, sodium, dan phosphor, serta mikro elemen seperti mangan, zinc, dan besi.

Substitusi tepung ikan dengan tepung daun kelor terfermentasi sebesar $10 \%$ memberikan pertumbuhan berat terbaik, sedangkan substitusi hingga $15 \%$ tidak berpengaruh terhadap panjang, FCR dan PER nila merah (Faradia, 2018). Sedangkan Anwar et.al (2007) melaporkan bahwa biji kelor merupakan bahan alami yang terbaik yang berperan penting dalam pengelolaan air untuk memperbaiki kualitas air, mereduksi logam berat, bakteri Escherichia coli, alga serta sebagai surfaktan. Serbuk biji kelor mampu menurunkan konsentrasi fosfat total pada dosis 200 ppm dengan waktu pengendapan 90 menit sebesar $27,82 \%$ atau 8,068 ppm dan ortofosfat sebesar 29,87\% atau 3,195 ppm (Khasanah, 2008)

Hasil penelitian sebelumnya menunjukkan bahwa biji kelor dapat berperan sebagai koagulan alami dalam mengatasi pencemaran air limbah oleh pewarna sintetis (Tiea et al, 2015). Selanjutnya dilaporkan bahwa biji kelor merupakan bahan alami terbaik yang berperan penting dalam pengelolaan air untuk memperbaiki kualitas air, mereduksi logam berat, bakteri E. Coli, alga serta sebagai surfaktan (Beltrán et al. 2012). Namun belum diketahui bagaimana peran biji kelor dalam memperbaiki kualitas air apabila dijadikan sebagai pakan ikan mas. 
Berdasarkan hal tersebut diatas, sangat perlu dilakukan penelusuran pustaka mengenai pengaruh pemberian pakan menggunakan biji kelor terfermentasi yoghurt terhadap perbaikan kualitas air pada media budidaya serta sebagai bahan probiotik untuk peningkatan fungsi fisiologis ikan.

\section{B. METODE PENELITIAN}

Metode yang digunakan yaitu penelusuran pustaka. Pustaka yang digunakan berupa jurnal ilmiah nasional dan internasional. Jurnal ilmiah dengan tema evaluasi dan formulasi penggunaan biji kelor sebagai probiotik dan pengelolaan kualitas air pada media budidaya ikan dengan terbitan 10 tahun terakhir yang diterbitkan secara on line dari berbagai web jurnal dan google. Berdasarkan pencarian, diperoleh sebanyak 25 jurnal dan dilakukan scrining jurnal sehingga didapatkan 4 jurnal utama dan 21 jurnal pendukung sebagai pustaka yang menampilkan evaluasi dan formulasi penggunaan tepung biji kelor. Metode yang dipilih dalam artikel review ini terdiri dari 4 perlakuan yaitu, evaluasi pengujian koagulan,pH air dan immunitas pada ikan serta uji aktifitas anti bakteri biji kelor

\section{HASIL DAN PEMBAHASAN}

Hasil dari beberapa review artikel mengenai biji kelor disajikan berikut:

1. Pengujian kualitas air, Pengujian oleh (Helen K et,. All, 2012).

Tabel 1. Waktu Penggumpalan Air Limbah Minyak Goreng

\begin{tabular}{ccc}
\hline No Akuarium & $\begin{array}{c}\text { Waktu } \\
\text { Penggumpalan }\end{array}$ & $\begin{array}{c}\text { Waktu ikan dimasukkan ke } \\
\text { akuarium }\end{array}$ \\
\hline 1 & 13.19 & 14.19 \\
\hline 2 & 13.22 & 15.22 \\
\hline 3 & 13.23 & 16.23 \\
\hline 4 & 13.26 & 14.26 \\
\hline 5 & 13.27 & 15.27 \\
\hline 6 & 13.26 & 16.28 \\
\hline
\end{tabular}

Tabel 2. Pengukuran Daya Hidup Ikan Mas

\begin{tabular}{cccc}
\hline \multicolumn{4}{c}{ Koagulan Ekstrak Biji Kelor } \\
\hline Inisial Ikan & $\begin{array}{c}\text { Waktu Pretes } \\
\text { Tanggal 19 Feb } \\
\text { 2011(Pukul) }\end{array}$ & $\begin{array}{c}\text { Waktu Postes } \\
\text { Tanggal 21 Feb } \\
\text { 2011 (Pukul) }\end{array}$ & $\begin{array}{c}\text { Daya } \\
\text { hidup } \\
\text { (Jam) }\end{array}$ \\
\hline K1 & 14.26 & 14.26 & 48.00 \\
\hline K2 & 15.27 & 15.27 & 48.00 \\
\hline K3 & 16.28 & 16.28 & 48.00 \\
\hline$\sum$ & & & 144 \\
\hline
\end{tabular}


Tabel 3. Pengujuan koagulan tawas

\begin{tabular}{lccc}
\hline \multicolumn{4}{c}{ Koagulan Tawas } \\
\hline Inisial Ikan & $\begin{array}{c}\text { Waktu Pretes } \\
\text { Tanggal 19 Feb } \\
\text { 2011(Pukul) }\end{array}$ & $\begin{array}{c}\text { Waktu Postes } \\
\text { Tanggal 21 Feb } \\
\text { 2011 (Pukul) }\end{array}$ & $\begin{array}{c}\text { Daya } \\
\text { hidup } \\
\text { (Jam) }\end{array}$ \\
\hline T1 & 14.19 & 23.27 & 09.08 \\
\hline T2 & 15.22 & 02.53 & 11.31 \\
\hline T3 & 16.23 & 04.28 & 12.05 \\
\hline$\sum$ & & & 32,43 \\
\hline
\end{tabular}

Tabel 4. Perbandingan koagulan tawas dengan biji kelor

\begin{tabular}{|c|c|c|c|c|c|}
\hline \multicolumn{6}{|c|}{ Efektifitas Treatment } \\
\hline \multirow[b]{2}{*}{ No } & \multicolumn{2}{|c|}{ Koagulan Biji Kelor } & \multicolumn{2}{|c|}{ Koagulan Tawas } & \multirow[t]{2}{*}{ T-Test } \\
\hline & $\begin{array}{c}\text { Daya } \\
\text { hidup }\left(\mathrm{X}_{1}\right)\end{array}$ & $X_{1}^{2}$ & $\begin{array}{c}\text { Daya } \\
\text { hidup }\left(\mathrm{X}_{2}\right)\end{array}$ & $\mathrm{X}_{2}^{2}$ & \\
\hline 1 & 48.10 & 2.304 & 09.08 & 145,2025 & \\
\hline 2 & 48.12 & 2.304 & 11.31 & 27,9161 & \\
\hline 3 & 48.15 & 2.304 & 12.05 & 82,4464 & \\
\hline$\sum$ & 144.37 & 6912 & 32.43 & 355,565 & 0,021 \\
\hline
\end{tabular}

2. Pengujian Koagulan Biji Kelor oleh Ariyatun (2018).

Tabel 5. Pengukuran pH air setelah diendapkan

\begin{tabular}{cccc}
\hline Gelas Beker & Daun Kelor & Biji Kelor & Benalu \\
\hline A & 7,6 & 7,3 & 7,3 \\
\hline B & 6,2 & 7,1 & 7,2 \\
\hline C & 6.3 & 7,0 & 7,4 \\
\hline D & 6,6 & 7,7 & 7,5 \\
\hline
\end{tabular}

3. Pengujian Pada sampel Darah Ikan Mas oleh sSabryana N (2020).

Tabel 6. Pengamatan Limposit sebelum dan sesudah pemberian ekstrak daun kelor

\begin{tabular}{lcccc}
\hline & \multicolumn{4}{c}{ Dosis ekstrak daun kelor } \\
\cline { 2 - 5 } $\begin{array}{l}\text { Pengamatan } \\
\text { limfosit }\end{array}$ & $0 \mathrm{mg}$ & $50 \mathrm{mg}$ & $75 \mathrm{mg}$ & $100 \mathrm{mg}$ \\
\hline $\begin{array}{l}\text { Sebelum Pemberian } \\
\text { EkstrakDaun Kelor }\end{array}$ & $82,6 \pm 2,0 \mathrm{a} \%$ & $82,6 \pm 1,52 \mathrm{a} \%$ & $82,3 \pm 1,15 \mathrm{a} \%$ & $82,3 \pm 3,2 \mathrm{a} \%$ \\
\hline $\begin{array}{l}\text { Sesudah Pemberian } \\
\text { EkstrakDaun Kelor }\end{array}$ & $82,3 \pm 2,30 \mathrm{a} \%$ & $84,3 \pm 2,30 \mathrm{a} \%$ & $85 \pm 1 \mathrm{a} \%$ & $86 \pm 1,7 \mathrm{a} \%$ \\
\hline Setelah Uji Tantang & $67,6 \pm 2,51 \mathrm{a} \%$ & $79 \pm 2 \mathrm{~b} \%$ & $78 \pm 1 \mathrm{~b} \%$ & $78.6 \pm 1,52 \mathrm{~b} \%$ \\
\hline
\end{tabular}

Tabel 7. Pengamatan netrofil sebelum dan sesudah pemberian ekstrak daun kelor

\begin{tabular}{lllll}
\hline & \multicolumn{4}{c}{ Dosis ekstrak daun kelor } \\
\cline { 2 - 5 } Pengamatan netrofil & $0 \mathrm{mg}$ & $50 \mathrm{mg}$ & $75 \mathrm{mg}$ & $100 \mathrm{mg}$ \\
\hline Sebelum Pemberian & $13 \pm 1,73 \mathrm{a} \%$ & $13 \pm 1 \mathrm{a} \%$ & $12,6 \pm 2,08 \mathrm{a} \%$ & $12,6 \pm 3,21 \mathrm{a} \%$ \\
Ekstrak Daun Kelor & & & & \\
\hline Sesudah Pemberian & $12,6 \pm 1,15 \mathrm{a} \%$ & $12 \pm 1,73 \mathrm{a} \%$ & $12,3 \pm 0,57 \mathrm{a} \%$ & $12 \pm 3 \mathrm{a} \%$ \\
Ekstrak Daun Kelor & & & & \\
\hline Setelah Uji Tantang & $22,3 \pm 1,52 \mathrm{~b} \%$ & $15,6 \pm 1,15 \mathrm{a} \%$ & $16,3 \pm 1,52 \mathrm{a} \%$ & $15,6 \pm 1,1 \mathrm{a} \%$ \\
\hline
\end{tabular}


Tabel 8. Pengamatan monosit sebelum dan sesudah pemberian ekstrak daun kelor

\begin{tabular}{lcccc}
\hline & \multicolumn{4}{c}{ Dosis ekstrak daun kelor } \\
\cline { 2 - 5 } Pengamatan monosit & $0 \mathrm{mg}$ & $50 \mathrm{mg}$ & $75 \mathrm{mg}$ & $100 \mathrm{mg}$ \\
\hline Sebelum Pemberian & $4,33 \pm 0,57 \mathrm{a} \%$ & $4 \pm 1 \mathrm{a} \%$ & $4,33 \pm 0,57 \mathrm{a} \%$ & $4,66 \pm 0,57 \mathrm{a} \%$ \\
EkstrakDaun Kelor & & & & \\
\hline $\begin{array}{l}\text { Sesudah Pemberian } \\
\text { EkstrakDaun Kelor }\end{array}$ & $4,33 \pm 1,15 \mathrm{a} \%$ & $3,36 \pm 0,57 \mathrm{a} \%$ & $4,33 \pm 1,52 \mathrm{a} \%$ & $3,66 \pm 1,15 \mathrm{a} \%$ \\
\hline Setelah Uji Tantang & $10 \pm 1 \mathrm{~b} \%$ & $5,33 \pm 1,15 \mathrm{a} \%$ & $5,66 \pm 0,57 \mathrm{a} \%$ & $5,66 \pm 2,08 \mathrm{a} \%$ \\
\hline
\end{tabular}

Tabel 9. Pengamatan survival rate dan relative percent survival.

\begin{tabular}{lcc}
\hline Konsentrasi & SR $(\%)$ & RPS (\%) \\
\hline $0 \mathrm{ppm}$ & $43,33 \pm 11,5$ & - \\
\hline $50 \mathrm{ppm}$ & $76,66 \pm 5,77$ & $55,56 \pm 19,2$ \\
\hline $75 \mathrm{ppm}$ & $83,33 \pm 5,77$ & $72,22 \pm 9,62$ \\
\hline $100 \mathrm{ppm}$ & $73,33 \pm 15,2$ & $55,55 \pm 25,4$ \\
\hline
\end{tabular}

4. Pengujian uji aktifitas anti bakteri biji kelor oleh Wigunarti et al,.(2019)

Tabel 10. Pengukuran rata-rata diameter zona hambat ekstrak biji kelor (Moringa oleifera $L$ ) terhadap bakteri Staphylococcus aureus dalam pelarut polar dan non polar.

\begin{tabular}{ccc}
\hline & \multicolumn{2}{c}{ Rata-rata diameter zona hambat bakteri (mm) } \\
\cline { 2 - 3 } Konsentrasi $(\%)$ & Pelarut N-Heksan (non polar) & Pelarut Etanol 96\% (polar) \\
\hline 75 & 0,00 & 14,75 \\
50 & 0,00 & 13,16 \\
25 & 0,00 & 10,20 \\
$\mathrm{~K}+$ & 21,40 & 12,48 \\
$\mathrm{~K}^{-}$ & 0,00 & 0,00 \\
\hline
\end{tabular}

Tabel 11. Pengukuran rata-rata diameter zona hambat ekstrak biji kelor (Moringa oleifera L.) terhadap bakteri Escherichia coli dalam pelarut polar dan non polar

\begin{tabular}{ccc}
\hline & \multicolumn{2}{c}{ Rata-rata Diameter Zona Hambat Bakteri (mm) } \\
\cline { 2 - 3 } Konsentrasi $(\%)$ & Pelarut N-Heksan (non polar) & Pelarut Etanol 96\% (polar) \\
\hline 75 & 0,00 & 3,50 \\
50 & 0,00 & 3,40 \\
25 & 0,00 & 1,10 \\
K+ & 7,73 & 8,00 \\
$\mathrm{~K}^{-}$ & 0,00 & 0,00 \\
\hline
\end{tabular}

Review dilakukan terhadap terhadap bakteri Staphylococcus aureus pengujian kualitas air dan immunitas ikan dan Escherichia coli. Pada penelitian serta uji aktifitas anti bakteri biji kelor. K.Helen et,. al (2012), Ariyatun (2018), Evaluasi yang digunakan adalah evaluasi Sabryana.N (2020) dan Wigunarti et,.al pengujian koagulan, pH air, immunitas (2019) melakukan pengujian terhadap pada ikan serta daya hambat biji kelor efektifitas biji kelor untuk menunjang 
perbaikan lingkungan, sehingga dapat dimanfaatkan oleh organisme didalam perairan untuk meningkatkan kelangsungan hidupnya.

K.Helen et.,al (2012) menyatakan bahwa ikan mas yang di intervensi dengan koagulan ekstrak biji kelor memiliki ratarata daya hidup 4 kali lebih lama dibandingkan yang diintervensi dengan koagulan tawas, sehingga dapat menggumpalkan air limbah minyak goreng dalam lebih baik dari pada koagulan tawas. Dasar pertimbangan mengambil ikan mas (Cyprinus carpio L.) sebagai sampel penelitian bahwa ikan mas sangat peka terhadap perubahan lingkungan konsentrasi limbah, suhu, DO, $\mathrm{pH}$, salinitas dan alkalinitas Chahaya (2003). Pengujian dengan Efektifitas Treathment diperoleh $\mathrm{t}=0,022$ dengan harga kritis pada signifikansi $0,01=3,36$ dan signifikansi $0,05=2,02$ di dapat perbandingan $(0,022<2,02<3,36)$, bermakna bahwa penelitian ini signifikan baik pada signifikasi 0,05 . Hasil Uji $T$ dengan SPSS for windows didapat 0,021 artinya hasil penelitian signifikan ( $\mathrm{t}>$ 0,05), sehingga ekstrak biji kelor (Moringa oleifera) dapat digunakan sebagai koagulan alami yang aman bagi kehidupan ekosistem air mas.
Serbuk biji kelor sebagai koagulan efektif menurunkan kadar TDS dan TSS dalam limbah laundry yaitu dengan penurunan kadar TDS 74,07\% dan kadar TSS $89,29 \%$, dimana ukuran koagulan sebuk biji kelor, kecepatan pengadukan, waktu pengendapan dan perbandingan massa koagulan terhadap volume sampel berpengaruh terhadap persentase penurunan kadar TDS dan TSS. Kondisi optimum diperoleh pada ukuran serbuk koagulan > 100 mesh, kecepatan pengadukan sedang, waktu pengendapan 15 menit dan perbandingan massa koagulan terhadap volume sampel 1:19(mg/mL) Hak et., al (2018). Penurunan kadar TDS dan TSS dalam limbah laundry ini disebabkan oleh kandungan zat aktif 4-alfa-4 rhamnosyloxy-benzil-isothiocyanate dalam tepung biji kelor sehingga mampu mengadopsi dan menetralisir partikelpartikel lumpur serta logam yang terkandung dalam air limbah suspensi, dengan partikel kotoran melayang di dalam air (Dwi et.al 2007; Bey , 2010).

Selain itu biji kelor memiliki profil asam amino konsentrat protein biji kelor yaitu asam amino esensial $(\mathrm{mg} / \mathrm{g})$ berupa arginin $(77,3)$, fenilalanin $(27,61)$, leusin $(27,39)$, valin $(15,19)$, isoleusin $(13,16)$, treonin $(11,29)$ metionin $(10,67)$, lisin 
$(7,57)$, lisin $(7,57)$, triptopan $(3,49)$. Asam amino non esensial $(\mathrm{mg} / \mathrm{g})$ berupa asam glutamat $(97,19)$, prolin $(26,3)$, glisin $(24,74)$, alanin $(17,57)$, asam aspartat $(17,45)$, serin $(15,16)$, tirosin $(11,29)$, dan sisitein $(5,9)$ (Nurhayatai et.,al, 2018). Kandungan protein dalam serbuk biji kelor sangat berpotensi sebagai bahan nutrisi dalam pakan ikan. Adanya kandungan protein yang tinggi didalam ekstrak daun kelor telah dilaporkan oleh Subryana et al.,(2020) bahwa perlakuan dengan ekstrak daun kelor diberikan injeksi intramuskular 0,1 mL/ikan dengan konsentrasi $50 \mathrm{mg}, 75$ mg dan 100 mg, dapat meningkatkan kekebalan non-spesifik, yaitu total leukosit, total eritrosit, leukosit diferensial, aktivitas dan indeks fagositosis pada benih benih ikan nila (Oreochromis niloticus) yang terinfeksi Aeromonas hydrophila. Hasil uji ANOVA diferensial leukosit sebelum dan setelah pemberian ekstrak daun kelor menunjukkan tidak terdapat pengaruh nyata terhadap limfosit, neutrofil, dan monosit. sedangkan setelah uji tantang neutrofil dan monosit di dosis $0 \mathrm{mg}$ berbeda nyata dengan dosis $50 \mathrm{mg}, 75$ mg, dan 100 mg. Pada limfosit setelah uji tantang dosis $50 \mathrm{mg}$ berbeda nyata dengan dosis $0 \mathrm{mg}, 75 \mathrm{mg}$ dan $100 \mathrm{mg}$.
Penelitian oleh Sari et., al (2017) ; Wigunarti.,et al (2019) bahwa ekstrak biji kelor memiliki daya hambat terhadap Staphylococcus aureus dan Escherichia coli. Dari kedua ekstrak uji, ekstrak etanol 96\% biji kelor mempunyai potensi aktifitas anti bakteri tertinggi pada ekstrak n heksana terhadap bakteri Stahylococcus aureus dan Escherchia coli. Ekstrak biji kelor memiliki hambatan tertinggi terhadap bakteri Staphylococcus aureus pada konsentrasi $75 \%$ sebesar 20,75 mm dan bakteri Escherichia coli pada konsentrasi $75 \%$ sebesar $9,50 \mathrm{~mm}$. Rasio konsentrasi ekstrak $75 \%$ dengan control positif kloramfenikol sebesar 5 SI. Selain hal tersebut ekstrak biji kelor menurut Jahn (1986) mampu menghambat pertumbuhan bakteri $P$. aeruginosa dan $B$. subtillis dikarenakan pada biji kelor mengandung pterygospermin, moringine, glycosides 4-( $\alpha$-L-rhamnosyloxy)benzylisothio-cyanate dan 4- $(\alpha-L-$ rhamnosyloxy)-phenylacetonitrile. Zat-zat tersebut biasanya digunakan untuk menghambat pertumbuhan bakteri Bacillus subtilis, Mycobacterium phei, Serratia marcescens, E.coli, Pseudomonas aeruginosa, Shigella and Streptococcus.

D. KESIMPULAN 
Berdasarkan hasil review jurnal yang terkait dengan efektifitas tepung biji kelor terhadap perbaikan kualitas air dapat disimpulkan bahwa tepung beji kelor dapat meningkatkan kualitas air pada media budidaya serta mampu meningkatkan pertumbuhan dan sintasan ikan mas.

\section{UCAPAN TERIMAKASIH}

Ucapan terimakasih kepada

Direktorat Jenderal Pendidikan Tinggi Kementrian Pendidikan dan Kebudayaan yang telah mendanai kegiatan ini melalui program kreativitas mahasiswa 5 bidang, anggaran tahun 2020.

\section{DAFTAR PUSTAKA}

Aminah S,Ramdhan T,Yanis T.2015. Kandungan Nutrisi dan Sifat Fungsional Tanaman Kelor (Moringa oleifera).Buletin. Buletin Pertanian Perkotaan Volume 5 Nomor 2,

Ariyatun, Ningrum P, Musyarofah dan Inayah N.2020. Analisis Efektivitas Biji dan Daun Kelor (Moringa oleifera) Untuk Penjernihan Air.Jurnal.Walisongo Jurnal Of Chemistri. ISSN :2621-5985 (online); 2549-385X (print). DOI : https://doi.org/10.21580/wjc.v2i2.3 $\underline{103}$.

Anwar, F., Said, L., Ashraf, M., dan Gilani, A.H., 2007, Moringa oleifera: a Food Plant with Multiple Medicinal

Uses,Phytotherapy Research, 21: 17-25.

Aslamyah, S. 2006. Penggunaan Mikroflora Saluran Pencernaan sebagai Probiotik untuk Meningkatkan Pertumbuhan dan
Kelangsungan Hidup Ikan Bandeng. (desertasi). Bogor: Program Pascasarjana, Institut Pertanian Bogor.

Astuti, D.A.,D.R. Ekasusanti dan firdaus. 2005. Manfaat Daun Kelor (Moringa oleifera) Sebagai Pakan Ayam Pedaging. Proseding. Seminar Nasional Pengembangan Usaha Peternakan Berdaya Saing Dilahan Kering Fakultas Peternakan Universitas Gadjah Mada. Yogyakarta.

Beltrán-Heredia, J., Sánchez-Martín, J., Barrado-Moreno, M.M., 2012. Long chainanionic surfactants in aqueous solution removal by Moringa oleifera coagulant.Chem.Eng. J. 180, 128-136.

Bey, H.H. 2010. All Things Moringa The Story an Amazing Tree of Tree. www.allthings moringa.com.

Bhoomika R. G., B B Agrawal, K. G Ramesh dan Anita A. M, 2007. Phyto-pharmacology of Moringa oleifera Lam. An overview. Natural Product Radiance Vol. 6(4)

Budi, S., Karim, M. Y., Trijuno, D. D., Nessa, M. N., \& Herlinah, H. (2018). Pengaruh Hormon Ecdyson Terhadap Sintasan Dan Periode Moulting Pada Larva Kepiting Bakau Scylla olivacea. Jurnal Riset Akuakultur, 12(4), 335-339.

Budi, S., Djoso, P. L., \& Rantetondok, A. (2017, March). Tingkat Dan Organ Target Serangan Ektoparasit Argulus sp. Pada Ikan Mas Cyprinus carpio Di Dua Lokasi Budidaya Di Kabupaten Gowa, Sulawesi Selatan. In Prosiding Forum Inovasi Teknologi Akuakultur (Vol. 1, No. 1, pp. 939944).

Dwi, T.S., Morina Adfa, dan Novrianto Tarigan. 2006. Buah Kelor (MoringaoleiferaLamk.)Tanaman Ajaib yang dapat digunakan untuk 
Mengurangi Kadar Ion Logam dalam Air.Fakultas MIPA Universitas Bengkulu. ISSN 02162393. Jurnal Gradien Vol. 3 No. 1 Hal. 219

Faradia.E.S.2018. Pengaruh Substitusi Tepung Ikan Tepung Daun Kelor (Moringa oleifera) Terfermentasi dalam Pakan Terhadap Sintasan dan Pertumbuhan Nila Merah (Oreochromis sp.). Skripsi. Universitas Gajah Mada.

Hak A,Kurniasih Y,Hatimah H. 2018. Efektivitas Penggunaan Biji Kelor (Moringa Oleífera, Lam) Sebagai Koagulan Untuk Menurunkankadar Tds Dan Tss Dalam Limbah Laundry.Jurnal. Hydrogen. Vol.6 , No.2. p-ISSN: 2338-6487 e-ISSN: 2656-3061 pp.100-113.

Hanafiah, K A. 2004. Rancangan Percobaan Teori dan Aplikasi. PT. Raja Grafindo Persada. Jakarta.

K.Helen, H.Hamzah Dan Najmah,2012. Efektifitas Koagulan Ekstrak Biji Kelor (Moringa Oleifera) Terhadap Daya Hidup Ikan Mas (Cyprinus Carpio L.) Pada Pengolahan Air Limbah Minyak Goreng Restoran Cepat Saji X Di Palembang. Jurnal Ilmu Kesehatan Masyarakat.Vol.3. Nomor 01

Khasanah, H., 2008, Efektifitas Biji Kelor (Moringa oleifera, LAMK) Sebagai Koagulan Fosfat Dalam Limbah Cair Rumah Sakit (Studi Kasus di RSU Dr. Saiful Anwar Malang),Skripsi, Jurusan Kimia, Fakultas Sains dan Teknologi, Universitas Islam Negeri (UIN) Malang.

Kurniawan D,Suharman I, Adelina. 2019. Pengaruh Pemberian Fermentasi Daun Kelor (Moringa oliefera) dalam Pakan Buatan Terhadap Pertumbuhan Benih Ikan Gurami (Osphronemus gouramy). Jurnal.
Jurnal Perikanan dan Kelautan. Volume 24 No. 1

Miftahul, L., Khoiroh. 2008. Efektifitas Koagulasi Ion Paraquat (1,1Dimetil,4,4-Bipiridilium)

Menggunakan Biji Kelor (Moringa oleifera Lamk.). Fakultas Sains dan Teknologi Universitas Islam Negeri Malang. Skripsi. Hal. 7, 22-23.

Mukarromah L.2008. Efektifitas Bioflokulan Biji Kelor(Moringa Oliefera Lamk) Dalam Mengurangi Kadar Cr(VI).Skripsi.Universitas Negeri Malang.

Mustapa, K., 2011. Pemanfaatan Biji Kelor sebagai Adsorben untuk Meningkatkan Mutu Garam Evaporasi di Sulawesi Tengah. FKIP Universitas Tadulako, Palu.ISSN : 16933974. Jurnal. Eukariotik, Vol. 9. No. 1 Hal. 24

Nurhayati, Nelwida, Berliana. 2014. Pengaruh Tingkat Yogurt Dan Waktu Fermentasi Terhadap Kecernaan In Vitro Bahan Kering, Bahan Organik, Protein, Dan Serat Kasar Kulit Nanas Fermentasi. Buletin. Buletin Peternakan Vol. 38(3): 182-188. ISSN 0126-4400

Nurhayati,Mappiratu,Musafira.2018.

Pembuatan Konsentrat Protein Dari Biji Kelor (Moringa Oleifera L.)

Dan Analisis Profil Asam Amino.Jurnal. Kovalen, 4(1):24-32, E-ISSN: 2477-5398

Putra AN, Yuaninda A, Anarki SB,Syamsumarno MB,Mustahal, Hermawan D, Herjayanto M. 2020. Efek Penambahan Prebiotik Pada Pakan Berbasis Bahan Baku Lokal Untuk Meningkatkan Pertumbuhan Dan Kecernaan Pakan Ikan Nila Oreochromis Niloticus.Jurnal. LEUIT. Journal of Local Food Security.Vol 1.1. e-ISSN.

Sari R.K, Tina L ,Fachlevy A.F.2017. Efektifitas Biji Kelor (Moringa Oleifera) Terhadap Bakteri 
Escherichia Coli Dalam Upaya Pencegahan Penyakit Diare.Jurnal. Jurnal Ilmiah Mahasiswa Kesehatan Masyarakat. 2/No.6/ Mei 2017; Issn 2503-731x.

Saudale F,Boelan E.2018. Aktivitas Antibakteri Ekstrak Polar Dan Non Polar Biji Kelor (Moringa Oleifera) Asal Pulau Timor .NTT.Jurnal. Sains dan Teknologi. Vol. 7, No. 1. P-ISSN : 2303-3142 E-ISSN : 25488570

Simbolon,J.M.,Simbolon,M.,dan

Katharina,N.2007. Cegah Malnutrisi dengan Kelor. Kanisius, Yogyakarta.

Susilorini, T. E. dan Sawitri, M. E. 2007. Produk Olahan Susu. Jakarta : Penebar Swadaya

Subryana N, Wardiyanto dan Susanti O. 2020. Penggunaan Ekstrak Daun Kelor Moringa oleifera (Lam, 1785) Untuk Meningkatkan Imunitas Non Spesifik Benih Ikan Nila Oreochromis niloticus (Linnaeus, 1758) yang Diinfeksi Aeromonas Hydrophila. Journal of Aquaculture and Fish Health Vol. 9(3) DOI : 10.20473/jafh.v9i3.16321

Susilorini, T. E. dan Sawitri, M. E. 2007. Produk Olahan Susu. Jakarta : Penebar Swadaya

Tiea, J., Jianga, M., Lia, H., Zhanga, S., Zhangb, X. 2015. A comparison between Moringa oleifera seed presscake extract andpolyaluminum chloride in the removal of direct black 19 fromsynthetic wastewater. J. Industrial Crops and Products., 74: 530-534

Wigunarti AH, Pujiyanto S, Suprihadi A.2019. Uji Aktivitas Antibakteri Ekstrak Biji Kelor (Moringa oleifera L.) Terhadap Pertumbuhan Bakteri Staphylococcus aureus dan Bakteri Escherichia coli. Jurnal. Berkala Bioteknologi, vol. 2, no.2.
Winarno et al. 1980. Pengantar Teknologi Pangan . Jakarta: PT.Gramedia

Dehghani, M. et al., 2015. Combined Chlorhexidine-sodiumfluoride

Mouthrinse for Orthodontic Patients : Clinical and Microbiological Study. Journal section: Oral Medicine and Pathology, 7(5). 